\title{
POST-OPERATIVE PANCREATITIS
}

\author{
By ArChibald E. Carter, F.R.C.S. \\ From the Department of Surgery, Harvard Medical School, and the Peter Bent Brigham Hospital, Boston, Massachusetts
}

\section{Introduction}

Post-operative pancreatitis has been the subject of several recent reports which, together with a commentary on our own experience, are reviewed in this presentation.

The first reference to the condition was by Schneider and Sebening (1928) ${ }^{1}$ in a general discussion on pancreatitis. In 1949 , Millbourn ${ }^{2}$ made the first survey of pancreatitis following gastric resection, noting that $90 \%$ of all cases showed a rise in the serum amylase post-operatively, the rise being the highest when extensive duodenal mobilization had occurred and lowest when adherent ulcers were left behind. He came to the conclusion that the occurrence of post-operative pancreatitis depended upon the following conditions.

(I) Mechanical injury direct to the pancreas and especially to the pancreatic ducts.

(2) Vascular conditions.

(3) Spasm of the sphincter of Oddi.

(4) Stagnation of duodenal contents.

In this same year Metheney and Lundmark ${ }^{3}$, noting a case in which pancreatitis developed five days after a Polya type gastrectomy with retrocolic anastomosis quoted Horsley ${ }^{4}$ and Brunsgaard ${ }^{5}$ who reported the difficulties in recognizing the complication. Warren (195 ${ }^{6}$ and $1954^{7}$ ) reviewed the literature on the incidence of the condition after gastrectomy and recorded seven cases, six fatal, after 892 operations. He also quoted the aetiological factors stated by Millbourn, especially emphasizing the vascular effects.

Dunphy, Brooks and Ackroyd (1953) ${ }^{8}$ showed the condition could follow extensive mobilization of the head of the pancreas ( 5 cases), appendicitis ( $I$ case) and that in 2 cases the major lesion was thrombosis of vessels to the head of the pancreas associated with surgery elsewhere. Howard, Frewley and Artz (1955) ${ }^{9}$ state that serum amylase levels are usually lowered by surgery other than in the pancreatic area. Cope's (1938 ${ }^{10}$ and 1939 observations that adrenalectomy is followed by a rise in serum amylase and cortisone and Desoxycorticosterone acetate administration by a fall, provides experimental evidence for these observations in the light of current knowledge of adrenal and pituitary activity in trauma: similarly, Gray $(\text { I94I })^{12}$ showed that anesthesia produces a fall in serum amylase values.

During the course of this study, Perryman an Hoerr $(1955)^{13}$ reported their findings based upoi serum amylase determination. Excluding a mis. cellaneous group and their patients who had direst intervention on the pancreas, they showed that ifo of $3^{2}$ gastrectomies (type not stated) and 8 of 23 common bile duct explorations, showed a rise it serum amylase postoperatively: none of their $\varnothing$ simple cholecystectomies showed elevation in serum amylase after surgery though 2 of 8 vagotomies and gastrojejunostomies did. At this sam time, Mahaffey and Howard (1955) ${ }^{14}$ reported $2 \delta$ gastrectomies (type not stated) of which 7 showeed a rise of over $100 \%$ in serum amylase postope्य tively, 5 a slight rise and 8 a fall; of 28 operations on the biliary tract, 4 showed a rise above the high est normal level. They quote 50 other cases witg varying. changes though in some, for examples resection and grafting for aortic aneurysm, dire trauma to the pancreas is not definitely excluded. $\overrightarrow{\vec{F}}$

While there is no doubt that pancreatitis may follow many varieties of surgery even far away from the pancreas, pancreatitis following surgery in the pancreatic area, when the pancreas and its ducts have not been interfered with, is the condition. most likely to be confused with other postoperative complications in the area. The present observo tions were made to determine any precipitating factors in surgery in the pancreatic area and at the same time, an attempt has been made to exteng the usefulness of other serum pancreatic enzyms determinations.

\section{The Present Study}

This paper will be divided into two parts, first the results obtained by study of serum amylase and lipase levels, and secondly, by determination of serum trypsin inhibition.

Part 1. Observation on Serum Amylase Changes

Materials and Methods

Forty-four patients were studied, being selected 


\section{POST OPERATIVE PANCREATITIS}

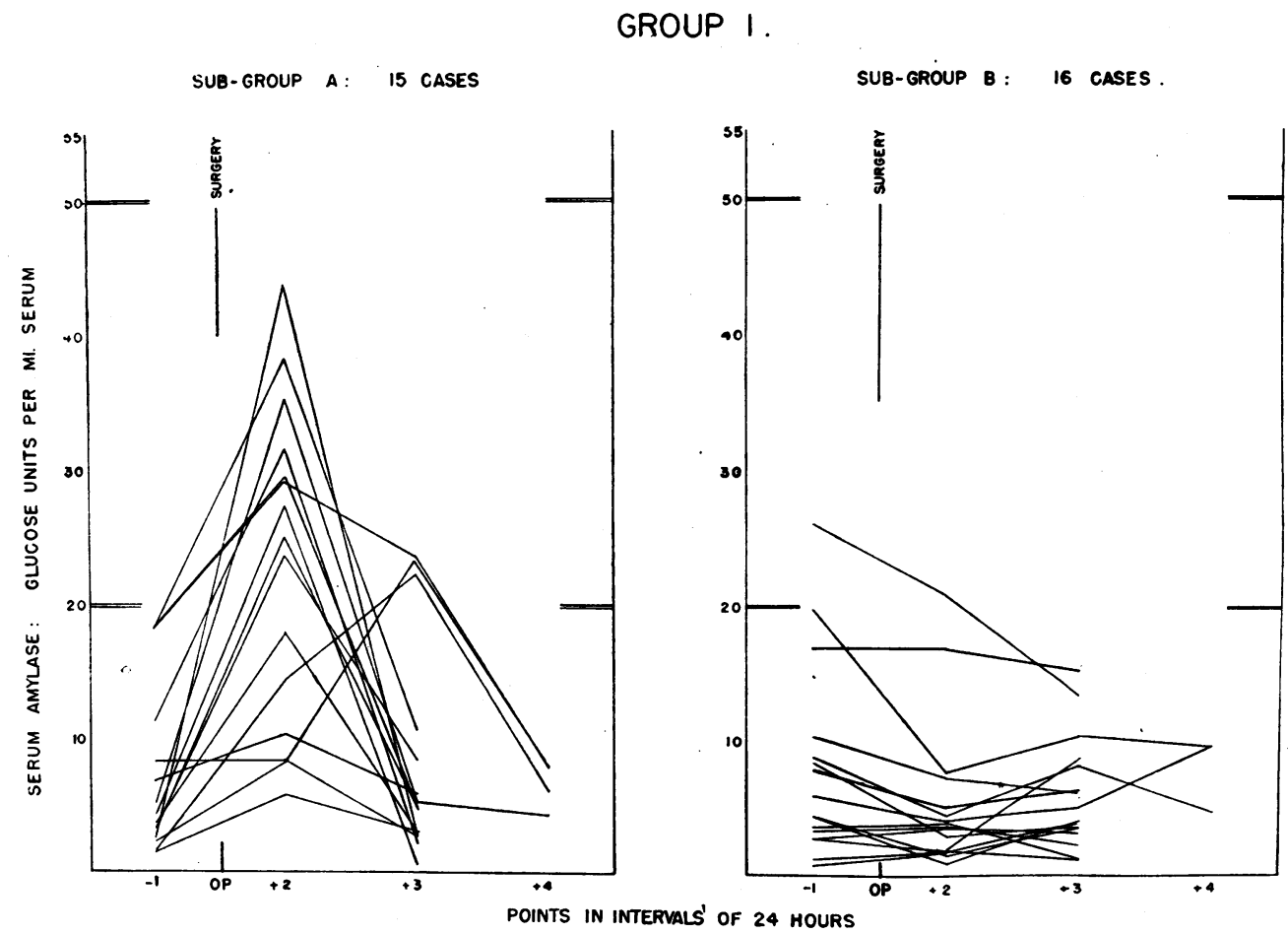

FIG. I.-Group I : 3 I cases, showing in Subgtoup A the usual ranges of elevation of serum amylase and in Subgroup B the ranges of fall or minimal elevation when there was no suspicion of pancreatitis.

irrespective of sex or age, from those undergoing simple cholecystectomy and simple gastrectomy to ascertain the changes in serum amylase levels in the first 24-72 hours after operation near to but not involving the pancreas directly. In this group are included, as comparison, patients who had common bile duct exploration or removal of peptic ulcers adherent to the pancreas. No patient had any part of the pancreas removed or mobilized. Two patients were studied during the course of an attack of acute pancreatitis, one before and one after surgery. Blood samples were collected 24 hours before surgery, 24 and 48 hours after surgery, and at 24 hour intervals until a normal level was reached. Normal levels were defined on 76 patients without pancreatic disease.

Serum amylase determination was by the method of Free and Myers (1944) $)^{15}$ reproducible to within $\pm .4 \%$. Normal levels lay between 0.78 and 20 glucose units per $\mathrm{ml}$. serum with a wide variability in individuals. In order to arrive at a level above which the presence of pancreatitis could be assumed, two standard deviations above the high- est normal levंel obtained were used, providing a figure of 50 glucose units per $\mathrm{ml}$. serum. Three patients known to have acute pancreatitis showed serum amylase levels between 70 and 286 units.

Serum lipase was also determined by Goldstein's (1948) ${ }^{16}$ method but although a satisfactory method, did not provide a wide enough range of change in result to be of aid in the problem and is not reported further.

\section{Results}

Serum amylase levels are presented as outlined above in the following groups.

\section{Group 1. (Fig. I)}

Illustrating the two types of change that may be expected in those patients whose serum amylase values never entered levels suspicious of their having pancreatitis.

Subgroup Ia. Fifteen cases, 12 of whom developed serum amylase levels above the highest normal (20 units) 24 or 48 hours after surgery. Six simple cholecystectomies, 2 common duct explora- 


\section{POST OPERATNE PANCREATITIS}

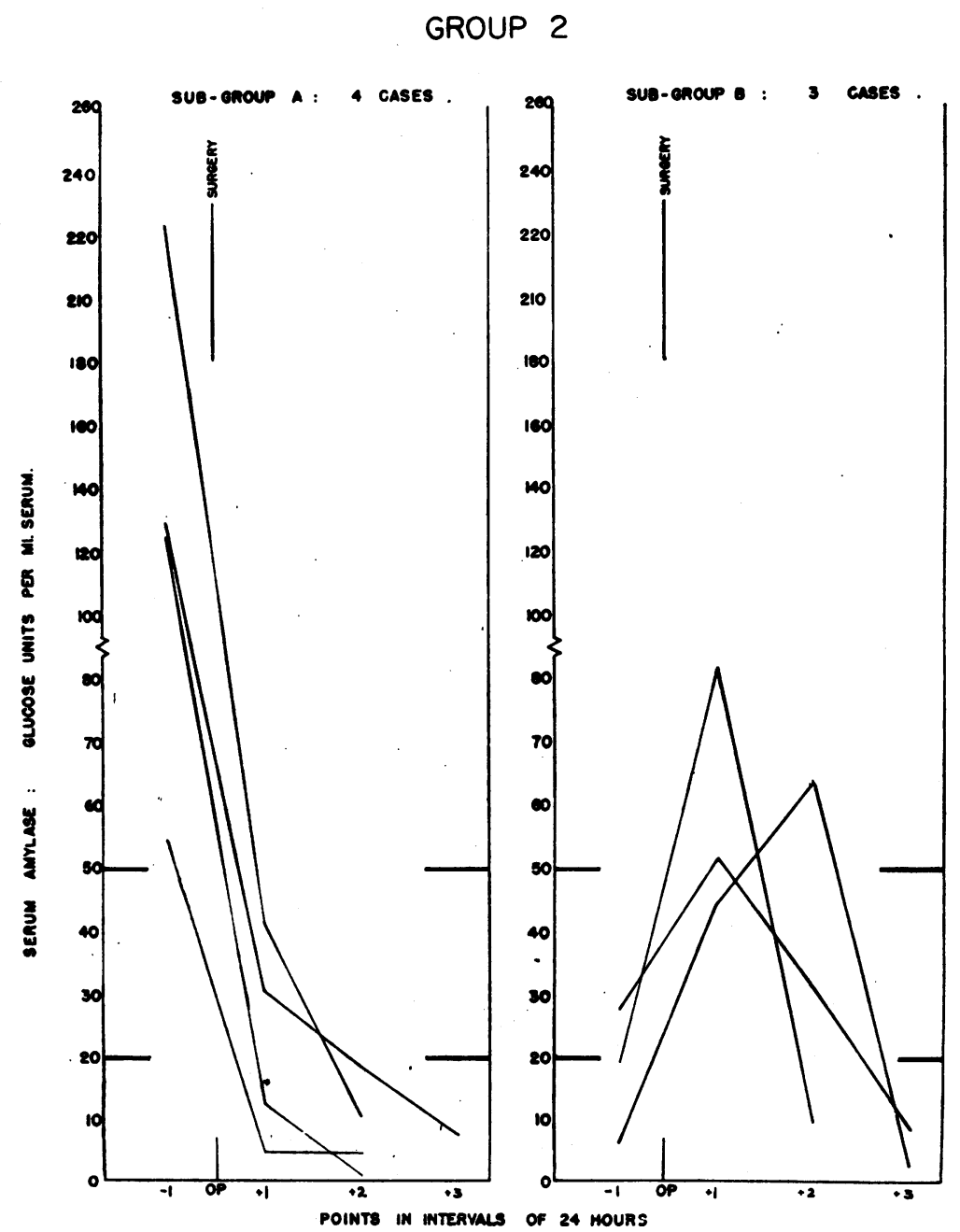

Fig. 2.-Group 2: 7 cases showing the falls from and rises into 'pancreatitis' levels in two subgroups when there was no suspicion of pancreatitis.

tions, 6 simple gastrectomies and I gastrectomy for adherent ulcer make up this group.

Subgroup $\mathrm{I} b$. Sixteen cases, who demonstrate the patterns of minimal change or fall in serum amylase after surgery. 6 cases had simple cholecystectomy, 2 common duct exploration, 7 simple gastrectomy, and I removal of an adherent gastric ulcer.

\section{Group 2}

Demonstrates in two subgroups those cases who although without clinical evidence of acute pancreatitis, had levels of serum amylase higher than the level (50 units) above which acute pancreatitis could be assumed present.
Subgroup $A$. Four cases, whose amylase level@ were over 50 before operation: 2 simple chole 0 cystectomies preceded by 'biliary colic', presum? ably from a stone impacted temporarily at the ampulla of Vater, I common duct exploration. similarly preceded by ' biliary colic' who had \& stone removed from the ampulla, and I case who had a simple gastrectomy for nonadherent, simplo gastric ulcer: this latter man had received 3,500 c. $\Theta$ of blood 24 hours before his serum amylase wă first estimated and it is thought that he may have had a mild pancreatic oedema as an allergie (Arthus) phenomenon. It is to be noted that theif surgery in no way prevented the fall in serum amye lase levels to be expected on relief of their disease 


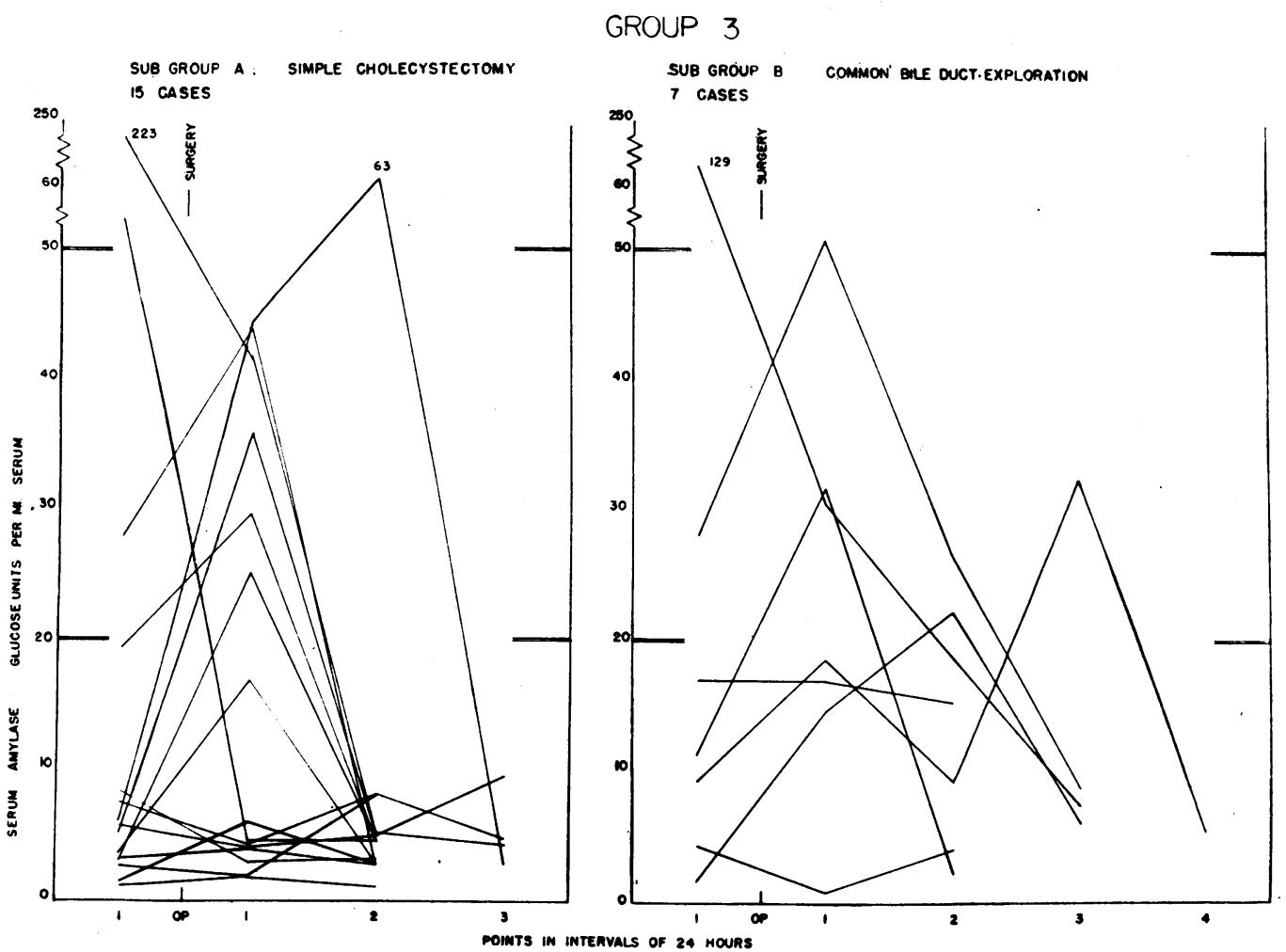

Fig. 3.-Group 3: 22 cases whose amylase levels before and after surgery for (a) simple cholecystectomy and $(b)$ common bile duct exploration are shown.

Subgroup $B$. Demonstrates 3 cases whose serum amylase levels reached over 50 units in the immediate postoperative phase. One of these whose highest level was reached at 48 hours, had a simple cholecystectomy for acute cholecystitis: at the time of surgery he was found to have an aortic aneurysm whose upper end was at the level of the coeliac artery and from which he died 6 weeks later. It is thought that he may have suffered a mild vascular interference to the pancreas associated with his aneurysm. The other cases represent levels reached after the exploration of the common duct and after excision of an adherent gastric ulcer. None of these three cases had clinical evidence of acute pancreatitis, each recovering uneventfully.

\section{Group 3}

This group, in all 39 cases, compared the simple procedure of cholecystectomy with the added trauma of exploration of the common bile ducts and simple gastrectomy with the effects of excision of an ulcer adherent to the pancreas. (Figs. 3 and 4.)

Subgroup $A$. Fifteen cases of simple chole- cystectomy. There is a relatively clear-cut distinction between those cases (six) whose serum amylase rose considerably (i.e., more than ro units) after surgery and those (six) whose amylase fell or rose only very little: two cases demonstrate the high preoperative amylase associated with ' biliary colic ' and one the high level as 48 hours associated with an aortic aneurysm. ${ }^{1}$

Subgroup B. Seven cases whose common bile ducts were explored illustrate that only one case just reached a level over 50 units, an incidence of I $: 7$ or $14.3 \%$.

Subgroup C. Thirteen cases subjected to simple gastrectomy: only 5 developed a postoperative level above the highest normal and even in the case with a very high preoperative level, it appears that there is little effect upon the pancreas, as estimated by serum amylase levels, as a result of performing a simple gastrectomy.

Subgroup D. Four cases whose peptic ulcers were 'shaved' off the pancreas are illustrated. One developed a level within the pancreatitis range though his clinical condition did not suggest his having pancreatitis; his ulcer was in the first part 




FIG. 4.-Group 3: I7 cases showing the alterations in pre- and post-operative serum amylase after (c) simple gastrectomy and $(d)$ removal of adherent peptic ulcers.

of the duodenum and he may well have had some temporary pancreatic duct obstruction.

\section{Group 4. (Fig. 5)}

These two cases are of special interest, being the only ones in this study who had clinical pancreatitis.

Case I. Demonstrates the levels of serum amylase reached during a severe attack of acute pancreatitis, starting 16 days before operation: after her recovery she underwent a simple cholecystectomy for chronic calculous cholecystitis following which her recovery was uneventful. She demonstrated only a small rise of serum amylase above the highest normal, falling into Groups IA and $3 \mathrm{~A}$.

Case 5. Following a cholecystectomy and exploration of the common bile ducts for stone, the operation passing without difficulty, she developed a moderately severe acute pancreatitis on the second day after operation. Her serum amylase levels are illustrated and it is to be noted that her amylase was higher on the second than on the firs $\mathrm{B}$ day.

\section{Comment}

Over the whole group, 4 cases (9.75) developed. postoperative serum amylase levels above the aro bitrary limit for the diagnosis of pancreatitis. though only one had clinical pancreatitis. None of the simple gastrectomies had a postoperative amylase level that was suspicious and only one of the simplec holecystectomies $(6.25 \%)$ : commop duct exploration increased the incidence of high. (over 50 ) levels to $25 \%$ in biliary tract operation and, in the case of the gastrectomies, the removal of adherent ulcers produced a $25 \%$ incidence of suspiciously high levels.

Part 2. The Use of Serum Trypsin Inhibition Introduction

Storer and Kazdan (1953) ${ }^{17}$ showed parallef changes occur between serum amylase and serum trypsin activity in acute pancreatitis. In are 


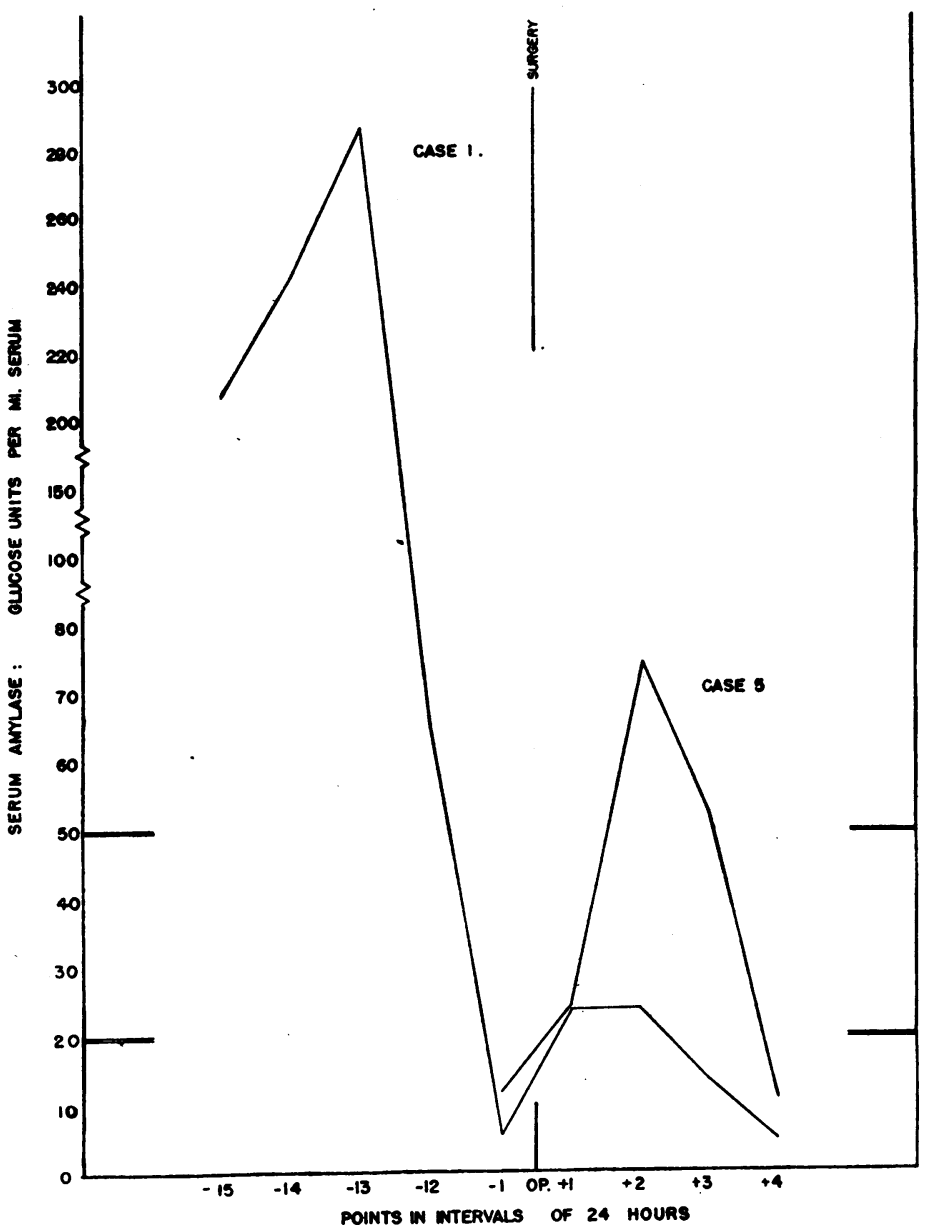

Fig. 5.-Group 4: 2 cases-cases demonstrating serum amylase levels in acute pancreatitis followed by cholecystectomy. Case 5-serum amylase levels in acute pancreatitis following common bile duct exploration.

attempt to find another laboratory procedure of simplicity which could help distinguish between those cases whose serum amylase levels rose to within the 'pancreatitis' range without clinical evidence of acute pancreatitis, and those whose levels similarly rose but developed clinical acute pancreatitis, an indirect procedure for measuring serum tryptic activity was adopted, using the capacity of serum to inhibit a standard quantity of trypsin.

\section{Materials and Methods}

Thirty-seven patients were selected from the group described in Part I. Their selection was based solely upon whether this trypsin inhibition had been studied or not. As serum on storage, even in the cold tends to increase its proteolytic and decreases its inhibitory action spontaneously, the samples were processed as soon as possible after collection.

\section{Preparation of Serum Trypsin Inhibitors}

Christensen's (1946) ${ }^{18}$ method of removal of the proteolytic components of serum was used, and the residual inhibitors then assayed against a standard of $0.1 \mathrm{mg}$. trypsin by the method of Free and Myers (1943) ${ }^{15}$. The result may be expressed in many ways but for simplicity in this 
POST OPERATIVE PANCREATITIS

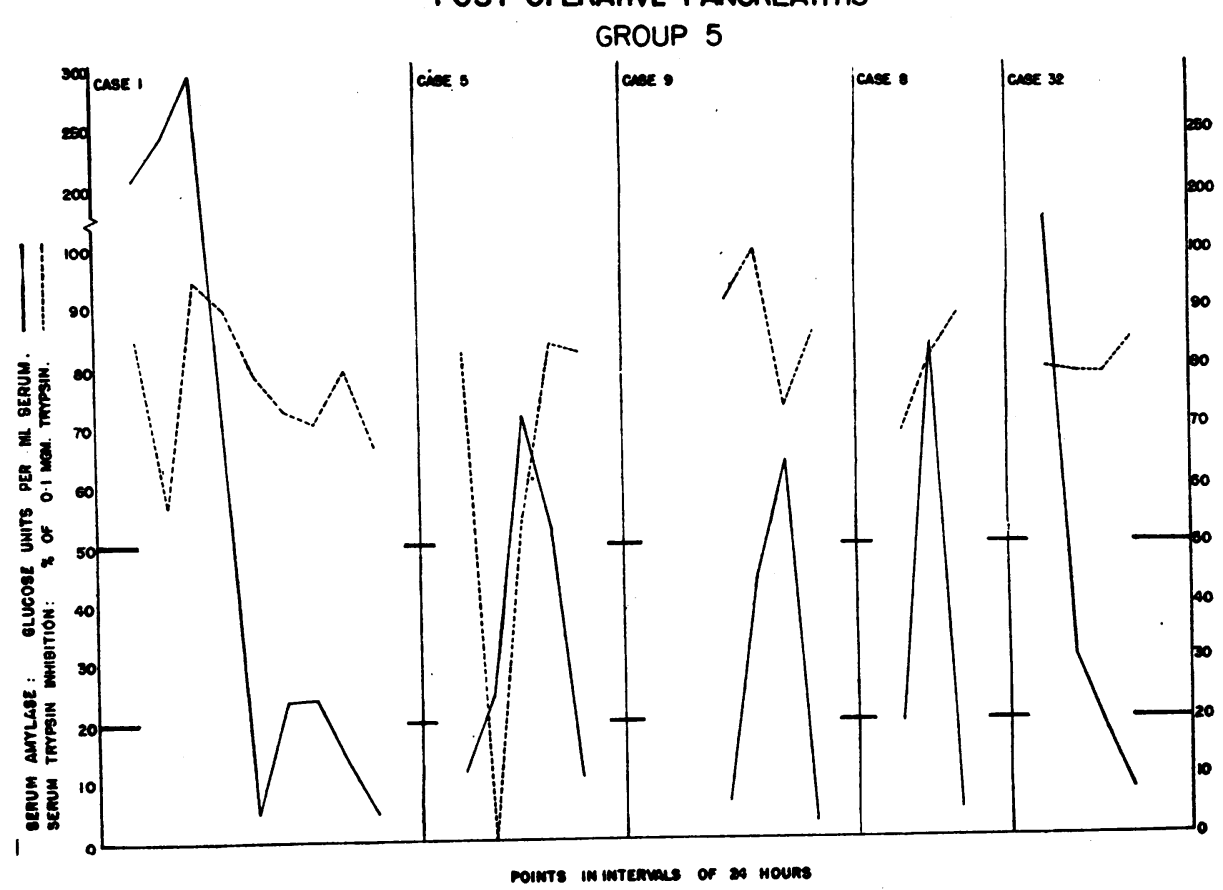

Fig. 6.-Group 5: Comparison of serum amylase and serum trypsin inhibition levels in acute pancreatitis (Cases $\mathrm{I}$ and 5 ) with others showing serum amylase levels in the 'pancreatitis' range but without clinical pancreatitis (9 cases in the group).

study it has been recorded as the percentage inhibition of o.I mg. trypsin: occasionally there has been complete inhibition in which case the test is repeated, using $0.2 \mathrm{mg}$. trypsin and the result expressed as a percentage over $100 \%$. It is felt that, although this method is indirect, the amount of inhibitor present in serum reflects inversely the amount of trypsin therein and might be an indicator of pancreatic activity in a fashion similar to serum amylase determination.

\section{Results}

The results will be presented in three groups corresponding to the three possible levels to which the serum amylase may rise or fall post-operatively. No distinction will be drawn between any surgical procedures.

\section{Group 5. (Fig. 6) (Table I)}

Serum Amylase Levels above $5 \circ$ glucose units per ml. serum (i.e., within 'pancreatitis' range).

In Fig. 6, cases $\cdot 1$ and 5 both developed clinical pancreatitis and the inverse change in trypsin inhibition and serum amylase is clear. Similarly in Case 9, (simple cholecystectomy with incidental aortic aneurysm) there is a marked inverse change. Cases 8 and 32 in Fig. 6 and the remainder of the group of nine patients demonstrated no such reta tionship.

Table I (Group 5)

SERUM Trypsin Inhibition Compared with SERUR AMYLASE LeVELS Over $5 \circ$ UNITS

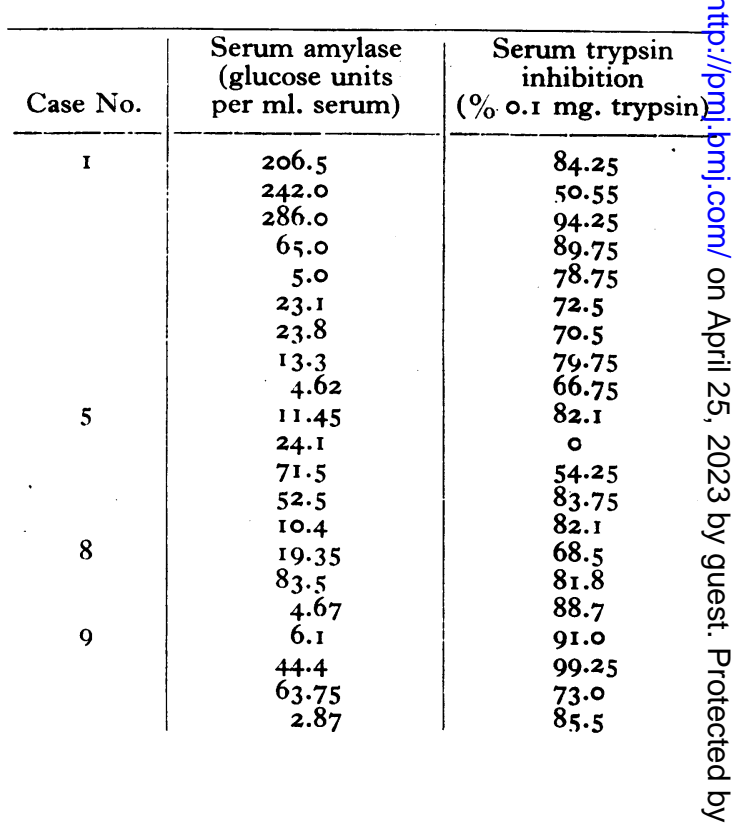


POST OPERATIVE PANCREATITIS

GROUP 6

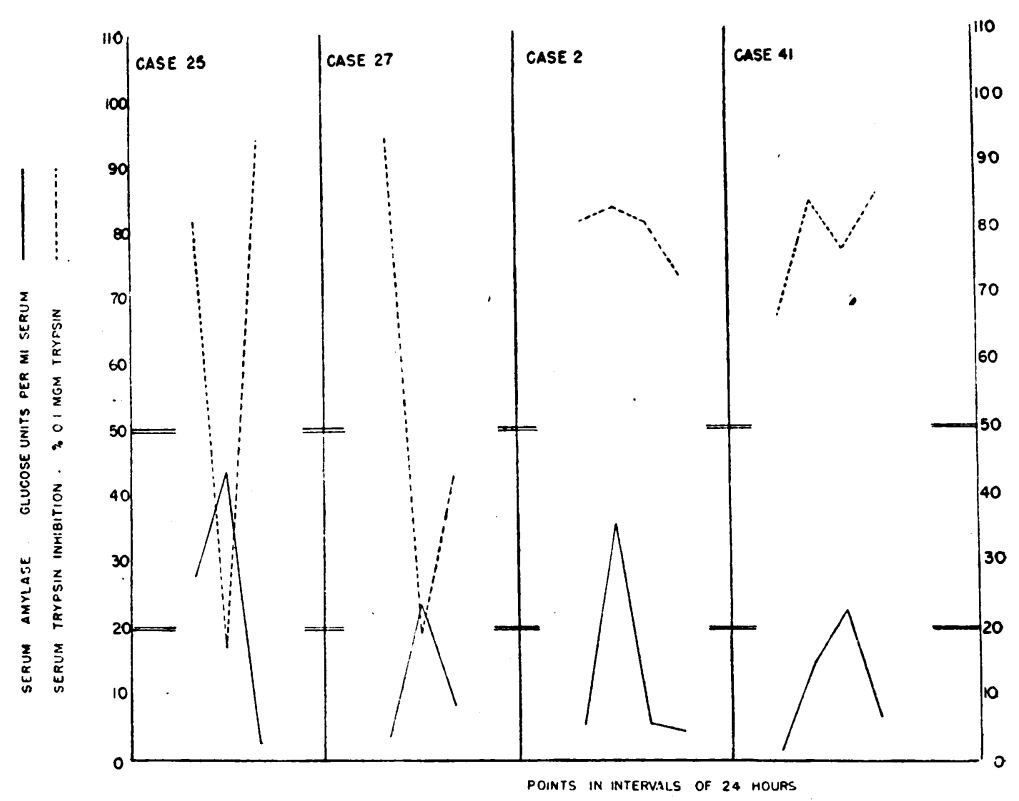

Fig. 7.-Group 6: 2 cases (25 and 27) showing the sharp fall in trypsin inhibition and 2 cases $(2$ and $4 \mathrm{I}$ ) not showing this fall in association with serum amylase levels in the range $20-50$ units ( 12 cases in the group).

TABLE I.-Continued

\begin{tabular}{|c|c|c|}
\hline Case No. & $\begin{array}{c}\text { Serum amylase } \\
\text { (glucose units } \\
\text { per ml. serum) }\end{array}$ & $\begin{array}{c}\text { Serum trypsin } \\
\text { inhibition } \\
(\% \text { o. I mg. trypsin })\end{array}$ \\
\hline 12 & $\begin{array}{r}223.0 \\
41.6\end{array}$ & $\begin{array}{l}76.0 \\
83.4\end{array}$ \\
\hline 14 & $\begin{array}{c}5.3 \\
\times 26.25 \\
12.65 \\
0.5\end{array}$ & $\begin{array}{l}71.25 \\
\text { I1.12 } \\
64.75 \\
79.2\end{array}$ \\
\hline 31 & $\begin{array}{r}54.5 \\
4.6 \\
4.6\end{array}$ & $\begin{array}{l}67.0 \\
79.4 \\
69.9\end{array}$ \\
\hline 35 & $\begin{array}{r}129.0 \\
30.4 \\
18.6\end{array}$ & $\begin{array}{l}79.25 \\
78.75 \\
78.25\end{array}$ \\
\hline 40 & $\begin{array}{c}7.45 \\
27.8 \\
51.5 \\
26.25 \\
8.7\end{array}$ & $\begin{array}{l}84.2 \\
61.0 \\
65.25 \\
71.0 \\
79.2\end{array}$ \\
\hline
\end{tabular}

Group 6. (Fig. 7) (Table 2)

Serum Amylase Levels above the highest normal (20 units) but below 'pancreatitis levels' (50 units).

In Fig. 6, four of the twelve patients in this group are illustrated. Cases 25 and 27 are seen to demonstrate the inverse change seen in Fig. 5 . Case 25 had an attack of 'biliary colic' 7 days before cholecystectomy and common duct exploration. Case 27 had an adherent gastric ulcer dissected from the pancreas. In the remainder of the figure and in Table 2, the usual absence of any regular correlative change in either estimation is seen.

Group 7. (Table 3) (Fig. 8)

Serum Amylase Levels Remaining within the Normal Range

The remaining 16 patients, 4 of whom are illustrated in Fig. 8, comprise the group in which there can be seen to be no correlation between serum amylase and serum trypsin inhibition levels.

\section{Comment}

While single estimations of serum trypsin inhibition, unless widely abnormal, are without value, a series taken at the same time as serum amylase values are assayed may be of value in determining which rises in serum amylase that would otherwise be only suspicious are, in fact, definite evidence of 
TABle 2 (Group 6)

Serum Trypsin Inhibition Compared with Serum AMYLASE LEVELS IN RANGe 20-50 UNITS

\begin{tabular}{|c|c|c|}
\hline Case No. & Serum amylase & Trypsin inhibition \\
\hline 2 & $\begin{array}{c}5.06 \\
35.6 \\
5.2 \\
4.32\end{array}$ & $\begin{array}{l}81.0 \\
83.0 \\
80.9 \\
72.5\end{array}$ \\
\hline 7 & $\begin{array}{l}18.2 \\
38.2 \\
10.6\end{array}$ & $\begin{array}{ll} & 28.65 \\
\cdot & 49.4 \\
& 48 . \mathrm{I}\end{array}$ \\
\hline 6 & $\begin{array}{c}9.25 \\
18.45 \\
9.25 \\
32.3 \\
5.4\end{array}$ & $\begin{array}{c}100.0 \\
100.0 \\
35.75 \\
88.75 \\
70.0\end{array}$ \\
\hline 18 & $\begin{array}{r}4.2 \\
27 \cdot 3 \\
0.5\end{array}$ & $\begin{array}{l}54.75 \\
78.3 \\
87.5\end{array}$ \\
\hline 19 & $\begin{array}{l}2.19 \\
8.1 \\
2.6\end{array}$ & $\begin{array}{l}82.0 \\
88.0 \\
85.5\end{array}$ \\
\hline 21 & $\begin{array}{c}8.03 \\
8.35 \\
23.1 \\
8.0\end{array}$ & $\begin{array}{l}97.75 \\
34.0 \\
93.0 \\
90.0\end{array}$ \\
\hline 25 & $\begin{array}{c}27.8 \\
43.8 \\
2.78\end{array}$ & $\begin{array}{l}81.25 \\
17.0 \\
94.0\end{array}$ \\
\hline 26 & $\begin{array}{r}3.64 \\
16.8 \\
2.96\end{array}$ & $\begin{array}{l}88.0 \\
99.0 \\
94.25\end{array}$ \\
\hline 27 & $\begin{array}{c}3.48 \\
23.6 \\
8.48\end{array}$ & $\begin{array}{l}94.0 \\
19.1 \\
42.75\end{array}$ \\
\hline 34 & $\begin{array}{r}11.25 \\
31.55 \\
2.14\end{array}$ & $\begin{array}{l}102.75 \\
108.75 \\
90.6\end{array}$ \\
\hline $4 \mathrm{I}$ & $\begin{array}{l}1.67 \\
14.5 \\
22.1 \\
6.19\end{array}$ & $\begin{array}{l}66.5 \\
83.6 \\
76.6 \\
84.75\end{array}$ \\
\hline 46 & $\begin{array}{c}3.19 \\
25.0 \\
4.68\end{array}$ & $\begin{array}{l}4.25 \\
79.0 \\
77.25\end{array}$ \\
\hline
\end{tabular}

the presence of pancreatitis when an inverse ratio is found.

\section{Discussion}

It is certain that, should there be much direct trauma to the pancreas or its ducts in such a way as to interfere with blood supply or drainage, the stage is set for the development of acute pancreatitis. Nevertheless, the complication is known to occur following the simplest and least traumatic
Table 3 (Group 7)

SERUM Trypsin INHIBITION Compared With SERUM AMYLASE LEVELS WITHIN NORMal RANGe (0.5-20 UNITS)

\begin{tabular}{|c|c|c|c|}
\hline Case No. & Serum amylase & \multicolumn{2}{|c|}{ Trypsin inhibition } \\
\hline 13 & $\begin{array}{c}19.7 \\
11.55 \\
10.4 \\
9.9\end{array}$ & $\begin{array}{l}87.2 \\
82.25 \\
71.2 \\
82.0\end{array}$ & $\begin{array}{l}\frac{\overline{0}}{+} \\
\frac{0}{0} \\
\frac{0}{0}\end{array}$ \\
\hline I 5 & $\begin{array}{l}2.6 \\
3.4 \\
3.2\end{array}$ & $\begin{array}{l}87.5 \\
75.2 \\
58.7\end{array}$ & $\begin{array}{l}\overline{8} \\
\stackrel{2}{0}\end{array}$ \\
\hline 17 & $\begin{array}{l}7.53 \\
4.37 \\
8.08 \\
4.85\end{array}$ & $\begin{array}{l}82.8 \\
79.25 \\
91.4 \\
70.0\end{array}$ & 心 \\
\hline 20 & $\begin{array}{l}7.7 \\
5.0 \\
6.4\end{array}$ & $\begin{array}{l}71.8 \\
70.0 \\
95.0\end{array}$ & $\vec{\omega}$ \\
\hline 24 & $\begin{array}{l}\mathrm{r} .25 \\
\mathrm{I} .68 \\
\mathrm{I} .25\end{array}$ & $\begin{array}{c}77.25 \\
76.7 \\
\text { I } 39.0\end{array}$ & $\cdot \frac{N}{\infty}$ \\
\hline 29 & $\begin{array}{l}16.9 \\
16.9 \\
15.3\end{array}$ & $\begin{array}{l}92.5 \\
95.0 \\
71.5\end{array}$ & \\
\hline 30 & $\begin{array}{l}3.25 \\
4.0 \\
2.28\end{array}$ & $\begin{array}{l}82.4 \\
84.9 \\
73.7\end{array}$ & 융 윰 \\
\hline 32 & $\begin{array}{l}1.49 \\
5.93 \\
2.97\end{array}$ & $\begin{array}{l}\text { 100.0 } \\
86.25 \\
69.5\end{array}$ & 흘 \\
\hline 36 & $\begin{array}{l}0.77 \\
1.7 \\
3.93\end{array}$ & $\begin{array}{l}50.0 \\
49.0 \\
88.0\end{array}$ & $\begin{array}{l}\frac{\bar{D}}{2} \\
\stackrel{0}{7}\end{array}$ \\
\hline 39 & $\begin{array}{l}26.0 \\
20.8 \\
13.6\end{array}$ & $\begin{array}{l}47.0 \\
61.0 \\
67.5\end{array}$ & 륨무 \\
\hline 42 & $\begin{array}{l}4.325 \\
0.86 \\
4.0\end{array}$ & $\begin{array}{l}70.5 \\
88.75 \\
88.0\end{array}$ & 믈 \\
\hline 43 & $\begin{array}{l}2.6 \\
1.72 \\
8.0\end{array}$ & $\begin{array}{l}80.8 \\
75.8 \\
92.0\end{array}$ & \\
\hline 44 & $\begin{array}{l}8.4 \\
2.98 \\
3.43\end{array}$ & $\begin{array}{l}77.75 \\
75.25 \\
77.25\end{array}$ & 吾 \\
\hline 45 & $\begin{array}{c}10.3 \\
7.28 \\
6.55\end{array}$ & $\begin{array}{c}73.75 \\
82.5 \\
120.0\end{array}$ & $\begin{array}{l}N \\
\text { N } \\
\text { W } \\
\sigma\end{array}$ \\
\hline 47 & $\begin{array}{l}4.32 \\
1.54 \\
3.54\end{array}$ & $\begin{array}{r}80.0 \\
101.0 \\
86.5\end{array}$ & $\begin{array}{l}\stackrel{0}{0} \\
\stackrel{7}{\Phi} \\
\stackrel{\$}{+}\end{array}$ \\
\hline 48 & $\begin{array}{c}6.85 \\
10.3 \\
5.9\end{array}$ & $\begin{array}{r}115.5 \\
92.5 \\
80.5\end{array}$ & $\begin{array}{l}\frac{0}{0} \\
\frac{0}{\mathbb{D}}\end{array}$ \\
\hline
\end{tabular}




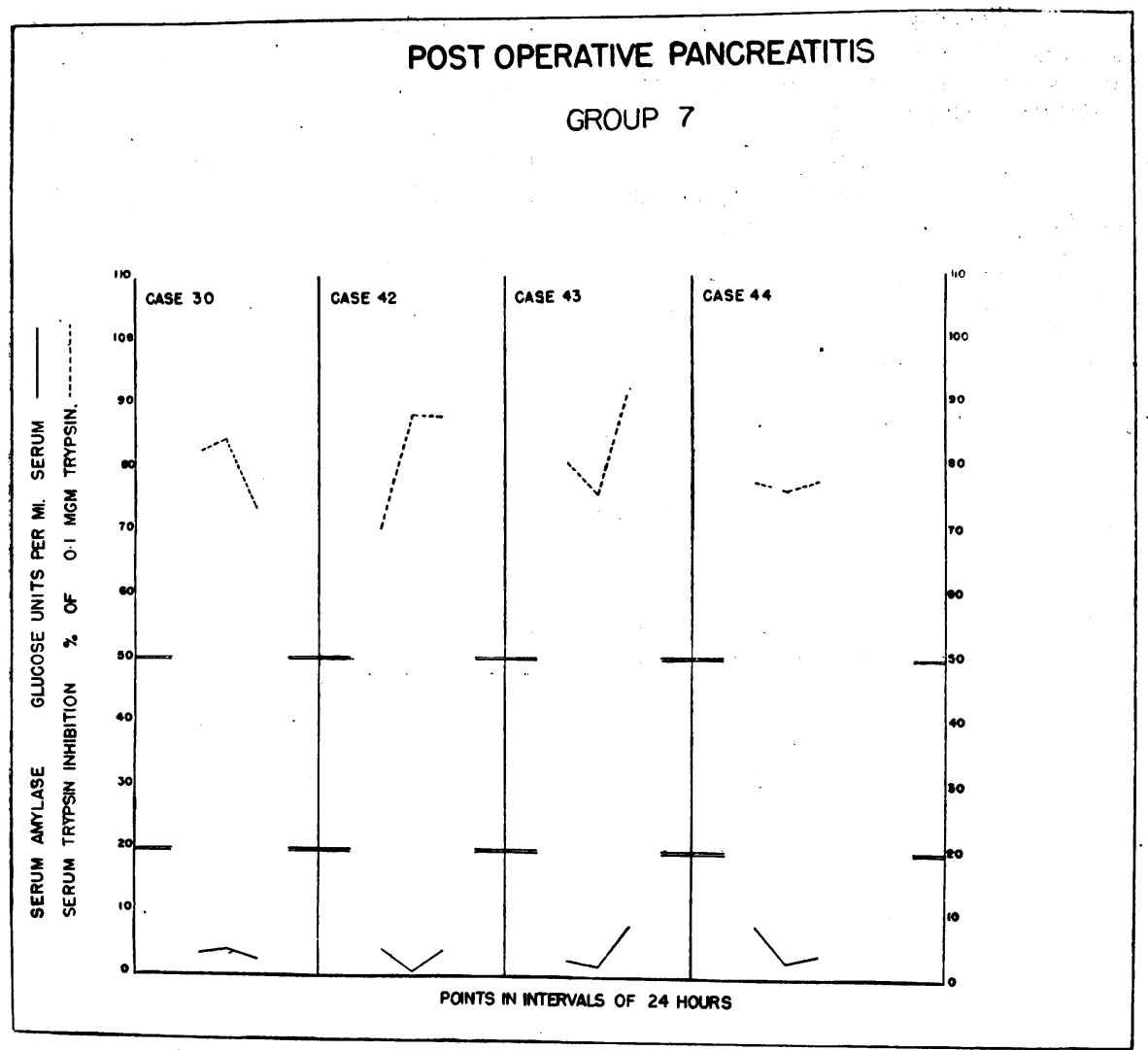

Fig. 8.-Group 7: 4 cases demonstrating no correlation between trypsin inhibition and serum amylase in the normal range (I 5 cases in the group.)

procedures in the pancreatic area and even, as reported by other authors, in areas well away from the pancreas. In these latter cases, acute pancreatitis presents as a complication fairly distinct from those that might be expected, and, provided it is kept in mind, should present little difficulty in recognition. There are, however, the troublesome few whose epigastric surgery, usually carried out without incident, is followed by acute pancreatitis at an early time in the post-operative period when it can be confused with other complications. Other investigators recently ${ }^{13},{ }^{14}$ have recorded their experience in these circumstances with evidence that the addition of common bile duct exploration to biliary tract surgery results in a higher proportion of elevated serum amylase levels and that between one third and one half of gastrectomies will show such elevation.

This study was directed to two aspects of the problem - firstly to discover any factors in surgery upon the biliary tract or stomach likely to encourage the development of pancreatitis, and secondly, any other tests or observations that could facilitate the diagnosis. Two patterns of response to biliary tract and gastric surgery in which the pancreas is not involved are clearly seen: there may be relatively little change in either the level of serum amylase or trypsin inhibition, or there may be a rise in amylase beyond the upper limit of normal but not to 'pancreatitis' levels without any corresponding change in trypsin inhibition. Even so, there is the occasional case whose amylase reaches 'pancreatitis' levels (in this series one case which probably could be included in the 'vascular conditions' group of Millbourne) after simple cholecystectomy ( 1 in $15-6.75 \%$ ). None of the simple gastrectomies reached suspicious levels, but removal of adherent ulcers showed a $25 \%$ incidence of suspicious levels ( 1 in $17-5.9 \%$ of all gastrectomies) and the passage of instruments along the common bile duct similarly increased the incidence to $I$ in $7(14.3 \%)$ of the group or 2 in 22 (9.1 \%) of all the biliary tract operations (Table 4).

There has often been little clinical suspicion of the presence of pancreatitis until a serum amylase estimation was done and the observations on the use of serum trypsin inhibition have been of value in these cases. As demonstrated in the two cases 
TABLE 4

Percentage of Cases Developing Serum Amylase Levels Post-operatively into the 'Pancreatitis' RANGE, OVER 50 UNITS

Operative procedures

Per cent. of cases with serum amylase levels over 50 units

Simple cholecystectomy .. 6.75

Common duct exploration

All biliary tract operations

Simple gastrectomy

Excision of adherent peptic ulcers

All gastric operations

I4.3

9.I

0

25.0

5.9

with undoubted pancreatitis, at the time when the serum amylase is rising, though not necessarily at its highest, there is a sharp fall in the inhibitory capacity due, it is believed, to the taking up of inhibitors by trypsin. The figures show that, assuming the concept to be valid, there is evidence that amylase levels do not have to rise even into 'pancreatitis' levels for the inhibition levels to show inverse ratios. In every case in which this inverse change occurred, there was either certain acute pancreatitis or the stage was set by possible vascular interference (Fig. 6, Groups 5 and 9), exploration of the common bile duct (Fig. 7, Group 6, Case 25), or the removal of an adherent peptic ulcer (Fig. 7, Group 6, Case 27). Case 8 (Fig. 4, Group 3D and Fig. 6, Group 5) is of interest in this regard: an adherent peptic (gastric) ulcer was shaved off the pancreas and the patient showed a high level (=83.5 units) of serum amylase without a corresponding fall in trypsin inhibition post-operatively. It is believed, therefore, that he did not have pancreatitis but his high level amylase was due to absorption of pancreatic amylase 'leaking' into the peritoneal cavity from the raw ulcer bed.

As a fall in trypsin inhibition is thought to be a reflection of a rise in blood trypsin level and a simple test to perform, it appears to be a useful additional laboratory procedure to distinguish between true pancreatitis, or its mild form, pancreatic oedema, from high serum amylase levels not indicative of pancreatitis. It is possible that the observation of a sharp fall in inhibition at a time that serum amylase level is even relatively low will indicate a predictable further rise in amylase and the development of pancreatitis; nevertheless single estimations of trypsin inhibition, not unlikes single estimations of serum amylase, are not always of significance and it is believed that, wheneve there is a suspicion of the possible development of pancreatitis, a series of tests should be performed

\section{Summary}

Observations on $4 \mathrm{I}$ patients undergoing biliar $\frac{\bar{\sigma}}{\bar{t}^{\circ}}$ tract and gastric surgery are presented. It i₹ demonstrated that serum trypsin inhibition is of value in distinguishing between high serum amys lase levels not due to pancreatitis and those due tढे the development of this condition after surgery The experience of the use of serum amylase levely alone on the assessment of precipitating factors ife the development of post-operative pancreatitis is presented.

\section{Acknowledgments}

I wish to express my thanks to Dr. Francis Dì Moore, at whose suggestion these observation $\overrightarrow{\$ 0}$ were made, for his continuous advice and en은 couragement, and to him and the members of the surgical staff of the Peter Bent Brigham HospitaR for allowing their patients to be studied.

\section{BIBLIOGRAPHY}

I. SCHNEIDER, V., and SEBENING, W. (1928), Surg. Gy and Obst., 46, 735 .

2. MILlBOURN, E. (1949), Act. Chir. Scand., 98, r.

3. METHENEY, D., and LUNDMARK, V. (1949), Northives Med., 48, 765 .

4. HORSLEY, J. SHELTON (1939), Ann. Surg., r10, 616.

5. BRUNSGAARD, C. (1946), Act. Clin. Scand. Suppl., ir7, 108С્

6. WARREN, K. (1951), Surgery, 29, 643.

7. WARREN, K. (1954), F.A.M.A., 154, 803 .

8. DUNPHY, J. E., BROOKS, J., and ACKROYD, F. (1953) New Eng. $\mathcal{F}$. Med., 248, 455 .

9. HOWARD, J. M., FREWLEY, J. P., and ARTZ, C. P. (I955) Ann. Surg., I41, 337.

ı. COPE, O. (1938), Am. F. Physiol., 122, 428.

I1. COPE, O. (1939), Endocrinol., 25, 236 and 248.

12. GRAY, S. H., PROBSTEIN, J. G., and HEIFETZ, C. (194I), Arch. Int. Med., 67, 805.

13. PERRYMAN, R. G., and HOERR, S. O. (1955), Am. F. Surg.

I4. MAHAFFEY, J. H., and HOWARD, J. M. (1945), Arch. Surg. $70,348$.

15. FREE, A. H., and MYERS, V. C. (1943), F. Lab. and Clin. Med., 28, $1,387$.

I6. GOLDSTEIN, J. (1948), Ibid., 33, I,047.

17. STORER, J., and KAZDAN, P. (1953), Surg., 33, 683.

18. CHRISTENSON, L. R. (1946-47), F. Gen. Physiol., 30, 149․ㅡㄹ. 